DOI 10.31392/NPU-nc.series15.2021.6(137).01

\author{
Gavrilova N. \\ senior lecturer at the Department of Physical Education \\ Mokhunko 0. \\ senior lecturer of the department of sports improvement \\ National Technical University of Ukraine Igor Sikorsky Kyiv Polytechnic Institute
}

\title{
PECULIARITIES OF USING RECREATIONAL AND HEALTH TECHNOLOGY IN THE SYSTEM OF PHYSICAL EDUCATION OF STUDENT YOUTH
}

The article analyzes the features of the use of recreational and health technology in the system of physical education of student youth. The basic principles of introduction of recreational and health-improving technologies during physical education classes are revealed. It is determined that fitness classes, aerobics, rhythmic exercises are the most popular among students, which significantly increases their level of motivation to exercise. It was found that the implementation of recreational and health technologies has a positive effect on improving the mental and physical condition and health of those involved. He recreational and improving technology consisting of the following organizational and methodical blocks is developed: improving and preventive - a complex of the pedagogical actions directed on strengthening and prevention of health of youth by modern means of physical culture and sports; climatic-biorhythmological - aimed at differentiation of health-improving and preventive measures for students depending on the time of year, climatic differences, examination sessions and the impact of the environmental environment; control and correction - pedagogical activities aimed at operational, current and phased control of physical and functional indicators of the health of young people during the day, week, month, semester, year and all time of study at the university; individual-independent - a set of pedagogical activities aimed at the formation of students' knowledge, skills and abilities of individual correction of health in the process of morning gymnastics, training, day, week

Key words: physical education, recreational and health technologies, physical exercises, fitness, health, students of higher education institutions.

Гаврилова Н., Мохунько О. Особливості використання рекреаційно-оздоровчої технології в системі фізичного виховання студентської молоді. В статті проаналізовано особливості використання рекреаційнооздоровчої технології в системі фрізичного виховання студентської молоді. Розкрито основні принципи впровадження рекреаційно-оздоровчих технологій під час занять з фізичного виховання. Визначено, що фітнес-заняття, аеробіка, вправи ритмічного характеру користуються найбільшою популярністю серед студентства, що значно підвищує їх рівень мотивації до занять фізичними вправами. Виявлено, що реалізація рекреаційно-оздоровчих технологій позитивно впливає на покращення психофізичного стану та рівень здоров'я тих, хто займається.

Ключові слова: фрізичне виховання, рекреаційно-оздоровчі технології, ффізичні вправи, фрітнес, здоров'я, студенти закладів вищої освіти.

Formulation of the problem. Human health is one of the highest and eternal values, and at the same time it is obviously a necessary condition for the development of the individual, the exercise of various social functions (reproductive, civil, labor, etc.). This is reflected in the Law of Ukraine "On Education», etc. Documents where the health of a young person is one of the main conditions for successful education and training. Improving the effectiveness of education and training is especially important in modern conditions, increased requirements for the level of professional competence of graduates, as well as in connection with the integration of Ukraine into the European system of higher education. The effectiveness of educational and professional activities depends not only on the quality of training, but also on the state of physical and mental health, individual capabilities of students, future professionals, the presence of the necessary professionally important qualities. Preserving the health of students and the full development of the individual is ultimately the general goal of education. In terms of modern education, there are negative trends in the health of students: a small proportion of students with a high level of general health; most students experience psycho-emotional stress due, among other reasons, to the mismatch between their chosen profession and their own interests. A characteristic feature of student youth is the low level of responsibility for their own health, the prevalence of health risk factors (smoking, alcohol, drugs, etc.). Urgent measures are needed to preserve, correct and increase health. This task is becoming one of the most important for all institutions and organizations involved in the upbringing and education of the younger generation.

In connection with the above, we can state the presence of a scientific problem characterized by the need to improve the system of physical education of students, the search for modern pedagogical technologies, forms and organizational pedagogical measures to improve the educational process in the discipline of "Physical Education" in higher education. and determined the relevance of the choice of research topic: «recreational and health technology in the system of physical education of students».

Modern higher education, being the most important institution of socialization of the individual, cannot stay away from the changes taking place in the Russian education system. Today, society is in demand for mobile people who are able to respond quickly and adequately to changes in the surrounding reality. Many do not have such abilities and have difficulty adapting to new living conditions. It is especially difficult for orphan students who do not have parents, due to the instability of their social status, instability of worldview, unreliable moral guidelines. In this regard, orphan students experience great psychological and physical overload, which negatively affects their personal development and health.

Analysis of literature sources. According to the scientific works of Yu. Belyak (2011), V. Sosina, A. Nakonechna (2010), Yu. Usachova, V. Zinchenko, V. O. Zhukova, P. Kozubeya (2011), popular among modern youth is health aerobics, which, due to the emotional background and the use of simple and affordable dance and gymnastic exercises, has a positive effect on the body: 
strengthens the cardiovascular and respiratory systems, increases aerobic capacity, develops strength, flexibility, coordination of movements, improves general and strength endurance, helping to increase the level of physical fitness [3]. In view of this, the optimization of physical activity, as the main factor in improving the health of students, through the use of health fitness is relevant and socially important. And although fitness is a young type of exercise, it is developing very rapidly, which leads to the study of the problem of individualization of health fitness programs.

Thus, an important scientific and applied problem of inconsistency of existing approaches aimed at the formation of a high quality of life, the needs of society and the state. In this regard, it is important to develop the theoretical and methodological foundations necessary for the applied adjustment of quality of life with the use of recreational and health technologies.

Presentation of the main material of the study. It is established that students as a social structure is a group that is in the area of many risk factors. Students more often than their peers from other social groups, suffer from various diseases, social maladaptation, increased levels of anxiety and emotional stress. The following diseases are typical for student youth of the present time: myopia, dental caries, rheumatism, chronic pathology of the ENT organs and upper respiratory tract, nervous, cardiovascular systems, various forms of allergic conditions, etc. Against the background of the above sad facts even more dramatic is students' knowledge of health, healthy living, physical education and sports. Thus, 8-10\% of young people have basic ideas about morning gymnastics, diet, the dangers of smoking and alcohol consumption; morning gymnastics is done regularly by $4-7 \%$ of students, $6-7 \%$ are engaged in sports sections. Summing up the analysis of the social sphere of life and health of young people, we can say that there is a negative demographic trend of youth in our country.

An analysis of current health technologies has shown that many of them are outdated and do not meet modern requirements for the health of student youth; other cumbersome in content, requiring primarily large material and financial costs; there are technologies that are only good "on paper" and cannot be adapted to life due to the great detachment from the realities of life; the state, unfortunately, is not always ready to react quickly and flexibly to the developments of scientists in order to quickly implement them in practice.

At the student age, the physical maturation of the body is completed, the process of comprehensive improvement of motor function is close to completion, the formation of the topography of the strength of various muscle groups, which are typical for adults, ends. By the age of 18-20 the formation of vegetative functions is completed and a high level of their interaction is reached. By this time, endurance, one of the most important motor skills for real human activity, is $85 \%$ of the value of this indicator in adults. Thus, the student age can be called the final stage of progressive age development of psychophysiological and motor capabilities of the body.

The recreational and improving technology consisting of the following organizational and methodical blocks is developed: improving and preventive - a complex of the pedagogical actions directed on strengthening and prevention of health of youth by modern means of physical culture and sports; aimed at differentiation of health-improving and preventive measures for students depending on the time of year, climatic differences, examination sessions and the impact of the environmental environment; control and correction - pedagogical activities aimed at operational, current and phased control of physical and functional indicators of the health of young people during the day, week, month, semester, year and all time of study at the university; individual-independent - a set of pedagogical activities aimed at the formation of students' knowledge, skills and abilities of individual correction of health in the process of morning gymnastics, training, day, week, etc.

Physical education can be a means of strengthening the health and improving the level of physical fitness of students, provided that its organization is based on the principles of regularity, background and flexible variability, which reflects the specifics of educational work. Attempts by most researchers to increase the efficiency of the process of physical education of students are characterized by one-sided approaches. Usually the issues of rational time planning, improving performance, physical and technical fitness, improving health and others are studied separately [5]. Researchers have proved that the content of compulsory physical education, which contains only basic sports, does not attract student youth [2]. In addition, when designing physical education programs, students usually take into account only the nature and severity of the disease. Classes are built according to a standard scheme and do not take into account the individual characteristics of students and their desire to engage in certain types of physical culture and health activities [6]. To increase motivation to exercise, scientists recommend the use of various health-improving technologies of conditioning training, namely: shaping, aerobics, pilates, callanetics, etc.

Over the last decade in Ukraine, the health and physical fitness of students among young people has deteriorated, which is primarily due to the crisis in the national system of physical education, which does not meet modern standards and international standards of physical fitness. human [1]. The tendency to deteriorating health is progressive.

The main idea of teaching physical exercises to students who have motor contraindications in their assimilation was a purposeful action on the motor analyzer, the formation of conscious automated components of the motor task. To do this, we used a repeated method of performing introductory and specially preparatory exercises to form a system of sequential conditioned reflexes, which is manifested in a dynamic stereotype. This is not about mastering the exercise to automatically perform a motor task, but about memorizing individual motor acts, which are psychologically formed into a holistic model of action. This approach is based on the formation of motor memory and ensures the preservation of the imaginary experience of the exercise being studied. This experience, which in normal conditions has a negative physiological effect, is manifested when necessary in the process of life due to the adaptive reactions of the organism to changes in environmental conditions. It is known that the comprehensive harmonious development of the individual provides adequate physical activity, it is one of the main factors determining the level of health of young people. It was noticed that taking into account the interests of students when choosing physical activity increases their motivation for physical culture and health activities in the conditions of sectional work and independent physical exercises.

Various means were used in the process of learning physical exercises: general developmental, special developmental, imitation, introductory and basic exercises, which were differentiated according to motor contraindications according to the diagnosis of diseases and psychophysical abilities of students with impaired health. The amount and intensity of exercise was dosed according 
to the speed and pace of exercise, number of repetitions per unit time, relative stress, range of motion, environmental resistance, time and conditions of exercise, duration and nature of rest between exercises, simplification of exercise structure in due to motor contraindications, a partial change in the method of exercise, starting position, etc [6].

New fitness technologies for health and recreational physical activity have become a natural result of the search for effective ways to provide organized physical activity available to the general population in order to promote health. The analysis of world experience and results of a number of scientific researches convinces that the effective direction of increase of level of motor activity of various groups of the population in Ukraine can become creation and introduction in system of physical training of youth and adult population of various popular fitness programs of improving, conditioning and sports directions as the most universal. type of physical activity.

Helping students become familiar with modern technologies of organized physical activity of various groups of the population during leisure time in order to restore working capacity, maintain health and improve the quality of life is the main task of this textbook. Active introduction of the latest technologies of organized motor activity in the practice of physical education and sports in Ukraine will help to involve the population in fitness and health sports.

In the conditions of severe economic and social crisis, low efficiency of state policy in ensuring the right of citizens to a proper quality of life there is an urgent need to develop and use fundamentally new and innovative approaches to realize the nation's potential, preserve health and efficiency. Today, the life of the population is the main indicator of the development and growth of any country in the world, a social standard and a priority in politics. However, given the semantic diversity of this concept, in different fields of science presented excellent methods of improving the welfare of the population. The direction of research, according to which the quality of life is considered as a complex medical and social phenomenon, is gaining active development in world science. This approach is crucial in modern international research and is gaining increasing support from Ukrainian scholars. The scientific community offers theoretical models that deepen the understanding of the relationship between a person's functional state and his or her well-being. The findings of these studies have become the scientific basis for the creation of evaluation systems that cover various areas of human life and society. and health education of people of all ages is unquestionable, there are only a few attempts to use the tools and opportunities available to this industry to ensure a high quality of life. Research on the directions and prospects of using special technologies (including physical culture and health) to ensure the quality of human life has allowed to solve only some scientific and practical issues of forming a proper quality of life. Improving the quality of life is not entirely identical to the solution economic problems, so the principles of forming a proper quality of life must be developed taking into account the best achievements of various branches of science. This problem is partly due to the fact that the factors that determine the quality of life are not fully understood and defined.

Conclusions. Physical education of students is part of the educational process. One of the urgent problems of physical education of student youth is reliable pedagogical control over determining the level of physical fitness. For the effective implementation and correction of recreational and health-improving technologies in the educational process of physical education of students, it is necessary to include the following organizational and methodological blocks: health-improving and prophylactic - a set of pedagogical measures aimed at strengthening and preventing youth health by means of physical culture and sports in the process of educational and daily activities; differentiation of health-improving and preventive measures aimed at strengthening the health of students, depending on the season, climatic changes and examination sessions; control and correctional - pedagogical measures aimed at operational, current and stage control of physical and functional indicators of youth health with their subsequent correction in the academic year and throughout the entire period of study at the university; individual-independent - a set of pedagogical activities aimed at the formation of knowledge, skills and abilities for an individual approach to personal health with subsequent selfcorrection.

\section{References}

1. Bubley T. (2016) Features of planning and organization of physical education lessons for students with impaired health: status and prospects // Scientific Journal. Series 15. "Scientific and pedagogical problems of physical culture (physical culture and sports)". Issue 3K 2 (71) 16. K .: Published by NPU named after M. Drahomanov. 53-55 p.

2. Griban, G., Tymoshenko, O., Arefiev, V., Sushchenko, L., Domina, Zh., Malechko, T., Zhuravlov, I., Tkachenko, P., Baldetskiy, A., Prontenko, K. (2020). The role of physical education in improving the health status of students of special medical groups. Wiadomości Lekarskie, 73 (3), 534-540. doi: 10.36740/WLek202003125.

3. Redkina M. Features of physical health of students which have low motor activity / M. Redkina // The scientific heritage № 46 (4) (2020). - Budapest, 2020. - P. 53-56.

4. Redkina Mariia Features of the using of infocomunication technologies in the process of physical education of modern youth // Materials of II International scientific conference (Kaunas, Lithuania, 22 February 2019). Lithuania, Faculty of Social Vytautas Magnus University. P. 296-298.

5. Shaposhnikova, I., Korsun, S., Arefieva, L., Kostikova, O., Serhiienko, V., Korol, S., Riabchenko, V. (2021). Analysis of students' somatic health and emotional state during sports games classes. Wiadomości Lekarskie, 74 (3 p.II), 608-612. doi: 10.36740/WLek202103208.

6. Tymoshenko, O., Arefiev, V., Domina, Zh., Malechko, T., Bondar, T., Tymchyk, M., Pliushchakova, O., Riabchenko, V., Griban, G., \& Prontenko, K. (2021). Exercise machines in speed and coordination development among students playing basketball. International Journal of Human Movement and Sports Sciences, 9(2), 347-355. doi: 10.13189/saj.2021.090224. 